OPTIMUM. STUDIA EKONOMICZNE NR 6 (78) 2015

Wojciech J. FLORKOWSKI, Grzegorz P. LYSIAK ${ }^{1}$

DOI: $10.15290 /$ ose.2015.06.78.12

\title{
OPPORTUNITIES FOR HORTICULTURAL PRODUCTION IN PODLASKIE VOIVODHSIP: PEARS FOR FRESH FRUIT MARKET
}

\begin{abstract}
Summary
Podlaskie Voivodship is located in a climatic zone perceived as unfavourable for pear production. This study examines production, trade and consumption of pears in Poland and argues that Podlaskie Voivodship can exploit the existing demand for pears in the region given the physiological opportunities resulting from the phenomenon known as parthenocarpy. Parthenocarpy permits production of pears despite the flower damaging spring frosts. Regionally important pear cultivars are recognized and consumed by residents in the area and in the neighbouring countries located to the East and Northeast of Podlasie. Although Podlaskie Voivodship plays a secondary role in tree fruit production in Poland, pear production is relatively more important in the region than in the country as a whole. Moreover, it appears that the pattern of large and small crops in the region and in Poland follow different pattern making Podlaskie Voivodship a reliable supplier of pears in when the pear crop may be particularly small in the country as a whole. The growing popularity of pears with Polish consumers and preferences for the familiar cultivars such as 'Beurre Alexandre Lucas' or 'Conference' produced in the region bodes well for producers, but attention to quality is necessary in the very competitive fresh fruit market. Additional markets in the neighbroing countries may offer additional opportunities for growers, who could expand pear production and benefit the regional economy.
\end{abstract}

Keywords: Fruit demand, parthenocarpy, pear variety, quality attribute, consumer preferences

\section{Introduction and objective}

Fresh fruit consumption in Poland has been increasing in response to growing disposable incomes in recent decades. The demonopolization of foreign trade led to increased imports of the fresh fruit further stimulated by the entry of multiple foreign retail chains. The increased accessibility of fresh fruit led to changes in the composition of fresh fruit basket consumed by Polish households. In general, per capita apple consumption, the most important domestically produced fruit, has been decreasing, while the consumption of imported fruit, especially tropical fruit has

\footnotetext{
${ }^{1}$ Professor Wojciech J. Florkowski - Department of Agricultural and Applied Economics, The University of Georgia, e-mail: wojciech@uga.edu. Dr inż. Grzegorz Lysiak - Faculty of Horticulture, Poznan University of Life Sciences, e-mail: glysiak@up.poznan.pl.
} 
been rapidly increasing [Klepacka et al., 2014]. Within Poland, regionally produced fruit has difficulties in gaining access to large distribution networks. As a result, any regionally important fruit sector faces the risk of extinction due to difficulties in accessing major distribution channels although the locally produced fruit is well known and accepted among local and regional consumers.

This paper describes the little known but substantial role of fresh pear production in Podlaskie Voivodship in Poland. Podlaskie is among the top regions in fresh pear production in Poland although the region is not known for horticultural production in general. The share of Podlaskie major fresh fruit production in Poland, including apples, plums, and sweet cherry is rather small. The exception, however, is pear production. Kacprzak [2004] noted the interesting case of an area around Bialystok, where pear production has been increasing, possibly due to the large concentration of consumers in the city and nearby foreign markets. We explain the biological reasons for increasing pear production in the area and illustrate the relative importance of Podlaskie in pear production by showing changes in the production area and crop size in Poland with a special emphasis on the period after the European Union (EU) accession on May 1, 2004.

After the EU accession, the fresh fruit trade intensified in Poland and the presence of supermarket chains from several EU-member countries has become increasingly visible across the country. For Podlaskie Voivodship, its own regional fruit production is relatively important as it generates jobs and income to rural residents in this depopulating area of Poland. In search of economic opportunities for the region, the pear sector has been missed, despite being the most important in relative terms to the region's horticultural sector. Podlaskie is known for the diary production, but the region is not competitive in other major agricultural enterprise. This paper fills the void in research about the horticultural sector in northeastern Poland and the underappreciated role of Podlaskie in the fresh pear supply. Indeed, the focus of the paper extends beyond the region because of the proximity of markets in countries bordering Podlaskie and other regions of Poland, including the largest urban market in Poland - Warsaw, the capital city.

\section{Natural growing conditions in Podlaskie and pear tree physiology}

The success of Podlaskie in pear production should not come as a surprise. Already Adam Mickiewicz in his poem reminisced about pear trees growing in the fields of his beloved Lithuania, located further to the northeast of Podlaskie Voivodship's capital, Bialystok. Although his record is unscientific, it illustrates that the pear tree was common in the area for centuries.

The scientific explanation of the success of producing pears under relatively harsh climatic conditions is the ability of pear tree flowers to set fruit even after a spring freeze destroys the flowers. The phenomenon is known as parthenocarpy and was reported in the scientific literature for many crops [Gustafson, 1942; Lysiak, Antkowiak, 2015]. Furthermore, the application of gibberelic acid during flowering to blossoms damaged 
by a deep freeze enhances the ability of a tree to set a large, commercially viable crop of pear fruit with parthenocarpy [Łysiak and Antkowiak, 2015]. Seedless fruit is not what nature intended in terms of propagation (as it has not been pollinated), but it is perfectly good for consumption. Indeed, studies suggest that such fruit tends to taste sweeter because of the higher total soluble solids (primarily sugars).

Podlaskie Voivodship is located in zone 6A and, in part, 5B according to the climatic zone map developed by the United States Department of Agriculture [Heinze, Schreiber, 1984]. The average annual temperature in Bialystok, the capital of Podlaskie Voivodship, is $7.1 \mathrm{C}$ and is substantially lower than the average $8.4 \mathrm{C}$ for Poland [Atlas Klimatu..., 2005]. In addition, the average number of days with frost in April is 21.2, while in May it is 5.6 days [Atlas Klimatu..., 2005], suggesting a high risk of frost damage to flowering pear trees. Flowering in the region may start at the end of April and likely occurs mostly in May. Therefore, the average weather conditions pose quite a challenge to pear growers in the region.

\section{Pear cultivars}

From a commercial pear orchard operator's perspective, the primary concern in Podlaskie Voivodship is frost tolerance and disease resistance. Lack of frost tolerance curtails any earnings, while pesticide treatment, primarily against scab, increases production costs. Although there are many pear cultivars [Błaszczyk, Łysiak, 2001; Lysiak, 2006] the three leading pear cultivars in Poland, suitable for the country's climatic conditions, are 'Beurre Alexandre Lucas' ('A. Lucas'), 'Conference' and 'Clapp's Favourite'. But in Podlaskie the conditions discourage plantings of 'Clapp's Favourite' in favor of 'Comice'.

Unfortunately, the data about regional distribution of pear cultivars are unavailable limiting the discussion to figures for the country as a whole and comments about the importance of the three varieties suitable for cultivation in Podlaskie Voivodship. The largest share is represented by 'Conference' according to data from 2012 [Wyniki badan GUS..., 2013b], which accounted for 29.5\%. This variety surpassed 'A. Lucas' which was the dominant variety with a share of $25.5 \%$ in 2004 . However, between 2004 and 2012, the plantings of 'Conference' increased substantially and in 2012, the majority of trees of this variety were no older than 14 years. In contrast, 40.4\% of 'A. Lucas' trees were older than 14 years. The age structure clearly suggests that new plantings are represented mostly by 'Conference'. The third variety suited for Podlaskie, 'Comice', accounts for only $0.8 \%$ of all pear trees in Poland [Wyniki badań GUS..., 2013b] and the age structure of trees shows that $34.9 \%$ are at most four years old.

The dominant cultivar 'Conference' is favored as a fresh fruit, unsuitable for processing. In Poland only 17\% of pears were processed in 2012 [Wyniki badań GUS.., 2013b], a considerably smaller portion than in the case of apples $(41 \%)$, sour cherries $(71 \%)$, or raspberries $(82 \%)$. 'Conference' cultivar stores well and in Podlaskie, as in much of eastern Poland, is ready for harvest at the beginning of October. The variety sets a large number of fruit and requires thinning, which in Podlaskie may occur naturally as a result of spring frosts [Łysiak, Antkowiak, 2015] . 
Its commercial popularity is likely determined by the early crop yield often in the second year after planting [Eysiak, 2006].

'A. Lucas' is likely the most popular cultivar in Podlaskie Voivodship because of its frost tolerance combined with annual fruiting (many cultivars of pears set crops in a biennial pattern). In eastern Poland it is harvested in the middle of October and it stores well through December and longer under controlled conditions (which probably is not widely used in Podlaskie). Fruit is sold as fresh fruit or for processing.

'Comice' is an old cultivar originating in France (like 'A. Lucas') and produces large, heavy fruits. Trees planted on seedling rootstocks take a long time to begin setting fruit (7-8 years), but grafted on vegetative rootstocks e.g. quince rootstock [Czernyszewicz, 2007] begin fruiting about four years after planting [Lysiak, 2006]. In eastern Poland this is the latest maturing among the three cultivars considered in this study - it is harvested in late October. This cultivar is only produced as fresh fruit and considered the tastiest pear in much of Europe [Łysiak, 2006].

It is possible that some new pear cultivars have been planted in Podlaskie. Unfortunately, the published Agricultural Census data do not provide sufficiently detailed information. Among such varieties may be 'Nojabrskaja' (trade name 'Xenia') bred in Moldova. The cultivar has a large annual crop, while relatively tolerant of frost and has high tolerance to pear scab and fruit tree canker (requires less application of fungicides), [Heijerman-Peppelman at al., 2009]. Interestingly, an individual fruit can weigh up to one kilogram on young trees [Lysiak, 2006]. There has been also an influx of pear cultivars from the Czech Republic, many of which tolerate spring frost, taste good, and are suitable for storage [Błaszczyk, Łysiak, 2001].

\section{Pear production}

The pear orchard area fluctuated between 2004 and 2012 in Podlaskie Voivodship (2012 is the last year for which GUS data are publicly available). The total number of hectares was 3400 in 2004 and declined to 2800 hectares in 2012. The declining pear orchard area in the region was similar to resemble the general tendency in Poland, where pear trees occupied an area of 14500 thousand hectares in 2004 [Badanie produkcii roślinnej..., 2005], but only 10800 thousand hectares in 2012 [Wyniki badan GUS..., 2013b]. Locally, like in the case of area around Bialystok, pear production has been expanding, so the change in the area produced involves also the shift in location of production. Moreover, the number of farms reporting growing pear trees declined by 30\% between 2002 and 2010 [Wyniki badan GUS..., 2013b], but the share of farms growing pears on two or more hectares has doubled, although it remains very small: $0.35 \%$ in 2002 vs. $0.7 \%$ in 2010 . Pears are produced primarily in small orchards of an area less than one hectare. The farm size in Podlaskie is larger than the average in Poland, but we lack information about the size of pear farms. A total of 2344 farms reported growing pear trees in Podlaskie in 2010 [Uprany ogrodnicze..., 2012], or 3.5\% of all pear-growing farms in Poland.

However, the share of pear trees among fruit trees in Podlaskie Voivodship has been contrasting with the total area decline and shown a growing tendency. The share 
amounted to $4.6 \%$ in 2004 and $8.1 \%$ in 2013; the highest share in the period considered in this study (Table 1). The observed increase in Podlaskie Voivodship sharply contrasts with the much smaller share of pear trees among fruit trees in Poland in 2004 (3.9\%) than in $2013(2.0 \%)$ [Rocznik Statystyczny Rolnictwa..., 2013; Rocznik Statystyczny Rolnictwa..., 2014]. The changes suggest the relative increase in the importance of pear orchards in fruit orchards in Podlaskie Voivodship making the region an interesting exception in the country.

Pear production has been highly variable between 2004 and 2013 [Rynek owoców $w$ Polsce, 2014]. The smallest crop was in 2007, 29 thousand tons, and the largest in 2004 when 118 thousand tons were harvested in Poland. The calculated mean and standard deviation of the national crop for the period 2004-2013 allowed the calculation of the varia coefficient of variation, which is applied as a measure of crop variability; it was 0.3506. Only after the comparison to the similar measure calculated for Podlaskie, 0.2470 , the measure shows much lower variability in annual pear crop. Lower variability of crop pear in Podlaskie suggests a more reliable crop volume and, indirectly, a more dependable supply. Supply reliability is a major factor in fruit business and Podlaskie as a region is able to assure relatively stable supply for the regional market and, possibly for neighboring countries.

The role of Podlaskie in pear production is particularly interesting because the years of large crops in the region do not necessarily correspond to years of large crops in Poland. The two largest crops in Podlaskie during the period under consideration were recorded in 2006 and 2011. The four largest pear crops in Poland during the period under consideration fell in 2004, 2008, 2009, and 2012. The smallest crop was in Podlaskie, the same as in Poland as a whole, in 2005 and 2007. However, the pattern of crops shows that pear production in Podlaskie counters the smaller crops in other parts of Poland at least in some years. Such pattern suggests favorable opportunities to market fresh pears from Podlaskie within and outside the region, fairly good news to pear producers there. It is possible that some pears from Podlaskie may have been exported because of the proximity of Lithuania and Belarus.

\section{Pear exports and imports}

Fresh fruit exports from Poland have been increasing in recent years. Apples are exported in the largest volume [Rynek owoców w Polsce, 2014]. However, between 2004 (the first year of Poland's membership in the EU) and 2013, pear exports nearly tripled, from 15 thousand tons to 42 thousand tons. The rapid growth of pear exports contrasted with the decline in exports of traditionally exported raspberries, black currants, and strawberries. However, it reflects the increasing importance of fresh rather than processed fruit. Only apple and sour cherry exports kept pace with the growth of pear exports.

The origins of pear imports to Poland suggest a complementary rather than competitive relationship to domestic production. In 2013, two of the largest pear exporters to Poland were Argentina and the Republic of South Africa [Import gruszek do Polski..., 2015], both located in the Southern Hemisphere where harvesting coincides 
with the late pear storage season in Poland. The largest exporter of fresh pears to Poland was the Netherlands; its exports accounted for 30.9\% of all pear imports to Poland in 2013. Belgian pear exports to Poland were about half of those of the Netherlands. Portugal also was a larger exporter of fresh pears to Poland: 2.9 thousand tons in 2013.

The comparison of total volume imported in 2013 to average annual crop of Podlaskie puts the imported volume of pears into perspective. The total volume of pears amounted to 22944 tons in 2013 and was markedly larger than the average pear crop in Podlaskie that amounted to 844 tons between 2004 and 2012. In 2013, pear imports represented less than $10 \%$ of the average pear crop in Poland; however, the imports accounted for 8.7\% of the average annual crop in Poland between 2004 and 2012.

\section{Consumer preferences}

Polish consumers have increased fresh fruit consumption in the past two decades. In this regard, Polish consumers follow the trend observed in other countries; for example, fresh pear consumption increased substantially in the 1990s in the United States [Moffit, 2002]. Pears are one of the most preferable fruits among the young Polish adults [Babicz-Zielinska, 1999]. The fundamental change is the composition of the fresh fruit basket where imported tropical or subtropical fruit accounts for an increasingly large share [Klepacka et al., 2014]. Domestic fruit, especially apples, have been consumed in increasingly smaller per capita amounts. The tendency is particularly visible in large cities, where imported fruit surpassed apples in terms of per capita consumption measured by weight of fruit. Changes in the composition of the fresh fruit basket include pear consumption. Pears have become available year round, largely through the supermarket network expansion, and domestic pears compete with imported pears of the same varieties. For example, 'Conference' is imported from Belgium and also produced in Podlaskie Voivodship. Consumer familiarity with 'A. Lucas' supports the continuing demand for this cultivar and is particularly important to Podlaskie. Studies from other countries indicate the importance of consumer prior expectations with regard to the appearance of pear fruits [Gamble et al., 2006]. Pear appearance and taste also influence the price consumers are willing to pay [Caputo et al. 2012], so these attributes require that growers in Podlasie pay attention to these attributes. Preferred quality attributes [Plocharski, Konopacka, 1999] combined with the local origin of pears, an important credence attribute [Gallardo et al. 2011] are a source of competitive advantage for the regional pear sector.

The future consumption of pears will be strongly influenced by fruit quality. Fruit originating in Podlaskie may have a narrow marketing window unless stored in a controlled atmosphere. Traditionally, local pears in Podlaskie have been available through Christmas, while the fruit retains good eating quality. Some volume may have been exported to neighboring countries including Lithuania and Belarus. The imported fruit and to some extent domestically produced pears in regions with milder climates may offer visually appealing attributes such as color. Cultivars currently grown in Podlaskie lack an appealing color making them less attractive if displayed next to colorful tropical fruit or apples. Eye-appeal in fresh fruit marketing is important. 


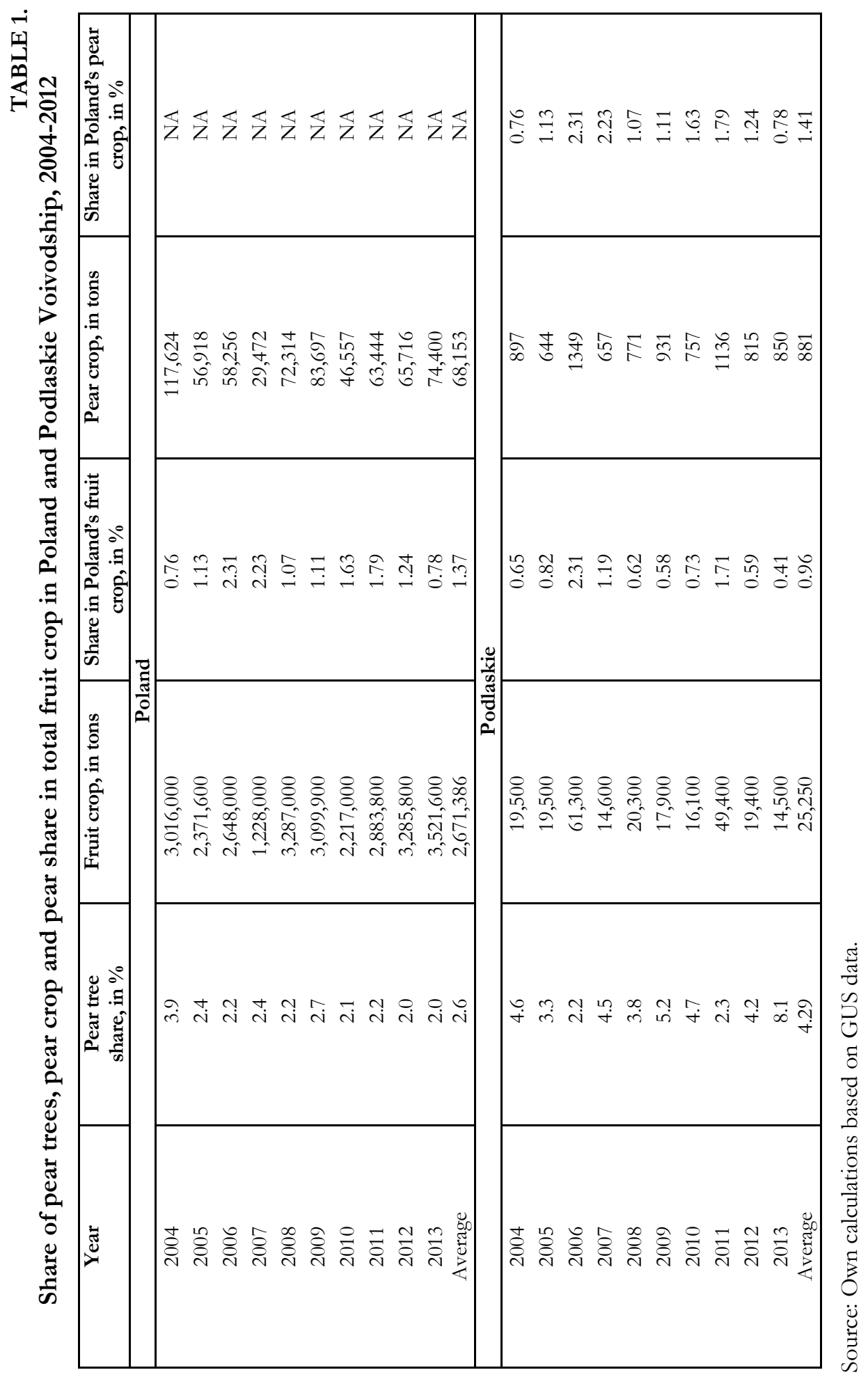




\section{Concluding comments}

The advantage of pear producers in Podlaskie is their location. On one hand, weather conditions permit pear production, and on the other hand, within a reasonable distance, pear shipments can reach nearby countries. Also, consumer preferences have been known to fluctuate, oscillating between novelty and heirloom varieties. Such fragmentation of preferences offers opportunities to market pears from Podlaskie in other regions of Poland, especially those where pear production is negligible. Finally, the increasing demand for cultivar as disposable incomes increase bodes well for the future of the pear industry in Podlaskie.

\section{Literature}

Atlas Klimatu Polski, 2005, IMGW, Warszawa.

Babicz-Zielinska E. 1999 Food Preferences among the Polish Young Adults, "Food Quality and Preference", 10, pp. 139-145.

Badanie produkcji roślinnej. Produkeja ogrodnicza. Badanie sadów, 2005, GUS, 20.06.2015 r., pp. 14.

Błaszczyk J., Lysiak G. 2001 Storage Properties of Czech Pear Cultivars Erica and Dicolor, "Journal of Fruit and Ornamental Plant Research", IX (1-4), pp. 71-76.

Caputo V., Canavari M. V., Nayga R. M. Jr. 2012 Selected Poster Paper Presented at the Agricultural and Applied Economics Association Annual Meeting, Seattle, August 12-14.

Czernyszewicz E. 2007 Zmiany w produkciji materiatu wyjsciowego dryewek na Lubelszçyźnie w latach 1994-2004, "Annales Universitatis Mariae Curie-Skłodowska - Lublin - Polonia", XVII(1), Sectio EEE.

Gallardo R. K., Kupferman E., Colonna A. 2011 Willingness to Pay for Optimal 'Anjou' Pear Quality, "Hortscience" 46(3), pp. 452-456.

Gamble J., Jeager S. R., Harker F. R. 2006 Preferences on Pear Appearance and Response to Novelty among Australia and New Zealand Consumers, "Postharvest Technology and Biology", 41, pp. 38-47.

Gustafson F. G. 1942 Parthenocarpy: Natural and Artificial, "Bot. Rev.”, 8(9), pp. 599-654.

Heijerman-Peppelman G., Bucarciuc V., Kemp H., Pasat O. 2009 'Xenia', A New Pear Cultivar from Moldova, First Results in the Netherlands, "Acta Horticulturae", 814, DOI: 10.17660/ActaHortic.2009.814.47, pp. 305-308.

Heinze W., Schreiber D. 1984 Eine neue Kartierung der Winterhärtezonen für Gehölze in Europa, „Mitteilungen der Deutschen Dendrologischen Gesellschaft”, 75, pp. 11-56.

Import gruszek do Polski w 2013 roku, 2015, GUS, available online at http://www.fresh-market.pl/owoce_i_warzywa/owoce/grusze/import_gruszek_do _polski_w_2013_roku,p1810508680, accessed: 24.02.2015.

Kacprzak E. 2004 Zmiany przestrzenne sadownictwa w Polsce 1990-2002, „Roczniki Akademii Rolniczej w Poznaniu", CCCLX, Ogrodn. 38, pp. 69-82.

Klepacka A. M., Meng T., Florkowski W. J. 2014 Apples or Oranges - Recent Household Fruit Consumption in Poland, „Zeszyty Naukowe SERiA”, 16 (6), pp. 255-259. 
Lysiak G. 2006 Uprawa i odmiany grussy, Hortpress, Warszawa.

Lysiak G. P., Antkowiak W. 2015 Quality Features of Parthenocarpic Pears Collected from Trees Grown on Different Rootstocks, „Acta Sciientarum Polonorum Hortorum Cultus",14 (5), pp. 69-82.

Moffitt K. 2002 Conditioned Fruit: Is it what Consumers are Looking for?, Proceedings of the Washington Tree Fruit Postharvest Conference, March 12-13, Yakima, Washington, USA, Available online at http://postharvest.tfrec.wsu.edu/PC2002H.pdf, accessed 21.04.2015.

Plocharski W. J., Konopacka D. 1999 The Relation between Mechanical and Sensory Parameters of Apples and Pears, „Acta Horticulturae”, 485, DOI: 10.17660/Acta Hortic.1999.485.43, pp. 309-318.

Rocznike Statystyczny Rolnictwa 2012, 2013, GUS, Warszawa, available online at http://stat.gov.pl/cps/rde/xbcr/gus/rs_rocznik_rolnictwa_2012.pdf. Accessed on February 26, 2015.

Rocznik Statystyczny Rolnictwa 2014, 2014, GUS, Warszawa, available online at http://stat.gov.pl/obszary-tematyczne/roczniki-statystyczne/roczniki-statystyczne/ rocznik-statystyczny-rolnictwa-2014,6,8.html, accessed 02.11.2015.

Rynek owoców w Polsce, 2014, Agencja Rynku Rolnego, Warszawa.

Uprany ogrodnicze - Powszechny Spis Rolny 2010, 2012, GUS, Warszawa, pp, 133.

Wyniki badań GUS. Produkcja ogrodnicza. Badanie sadón w 2012 roku, 2013, GUS, Warszawa, pp. 16. 